\title{
Lista de dissertações e teses 2011
}

\section{Dissertações de Mestrado defendidas em 2011/1}

\begin{tabular}{|c|c|c|c|c|}
\hline ORDEM & TÍTULO & MESTRANDO/A & ORIENTADOR/A & ÁREA \\
\hline 198. & $\begin{array}{l}\text { Produção de sentidos em contexto } \\
\text { escolar: o atravessamento da ideologia } \\
\text { na paráfrase discursiva. }\end{array}$ & Júlio César Albuquerque da Rocha & Helson Flávio da Silva Sobrinho & Linguística \\
\hline 199. & $\begin{array}{l}\text { Poesia e tecnologia em Araçá azul, de } \\
\text { Caetano Veloso }\end{array}$ & Tázio Zambi de Albuquerque & Susana Souto & $\begin{array}{l}\text { Estudos } \\
\text { Literários }\end{array}$ \\
\hline 200. & $\begin{array}{l}\text { Procedimentos de crítica à sociedade } \\
\text { brasileira do início do século XX em } \\
\text { Triste fim de Policarpo Quaresma, de } \\
\text { Lima Barreto }\end{array}$ & Ari Denisson da Silva & $\begin{array}{l}\text { Gilda de Albuquerque Vilela } \\
\text { Brandão }\end{array}$ & $\begin{array}{l}\text { Estudos } \\
\text { Literários }\end{array}$ \\
\hline 201. & $\begin{array}{l}\text { O imprevisível que rompe: análise de } \\
\text { manifestações do "que" em manuscritos } \\
\text { escolares de alunos do 2o ano do Ensino } \\
\text { Fundamental }\end{array}$ & Janaina Ligya da Rocha Silva & Eduardo Calil de Oliveira & Linguística \\
\hline 202. & $\begin{array}{l}\text { Da diversidade à desigualdade: os } \\
\text { (dês)caminhos de um discurso. Uma } \\
\text { análise dos PCN's e do LD de Geografia }\end{array}$ & Fabrisa Leite Barros da Silva & Helson Flávio da Silva Sobrinho & Linguística \\
\hline
\end{tabular}




\section{Lista de dissertações e teses 2011}

Teses de Doutorado defendidas em 2011/1

\begin{tabular}{|c|c|c|c|}
\hline ORDEM： TÍTULO & MESTRANDO/A & ORIENTADOR/A & ÁREA \\
\hline $\begin{array}{l}\text { Speech and smile in EFL classroom } \\
\vdots \text { interaction }\end{array}$ & Daniela Gomes de Araújo Nóbrega & Roseanne Rocha Tavares & Linguística \\
\hline $\begin{array}{l}\text { A responsividade ativa da professora: } \\
\vdots \text { suas leituras, suas produções e sua } \\
\text { : prática. }\end{array}$ & Antônio Cícero de Araújo & Rita Maria Diniz Zozzoli & Linguística \\
\hline $\begin{array}{l}\text { A revista Veja e os mecanismos de } \\
\text { construção de sentidos. }\end{array}$ & Ivete Aparecida da Silva Ota & Belmira Rita da Costa Magalhães & Linguística \\
\hline
\end{tabular}

